\title{
Leveraging Skype-based Webinars as an English Language Learning Platform
}

\author{
Arini Nurul Hidayati ${ }^{1}$, Tenia Ramalia ${ }^{2}$, Fuad Abdullah 3 \\ DOI: 10.35445/alishlah.v13i1.420
}

\begin{abstract}
Article Info Abstract
Keywords:

Online learning

Webinar

Skype

ELT

ELL

This present study reports 30 students' first learning experiences when using Skype in an English Language Teaching (ELT) webinar series. Since numbers of ELT webinars have been flourishing throughout the corona pandemic situation in 2020, the utilization of diverse online platforms to facilitate the events has also been growing. Skype, an online application released in 2003, was not widely used by the participants in this study as their synchronous virtual English Language Learning (ELL) platform. As a result, many of them were not familiar with this application. Underpinning Gibbs' reflective framework, this qualitative scrutiny documented the encountered shortcomings and advantages written in the participants' journal. This study's findings revealed that the Skype-based webinar provides opportunities to stimulate the students' learning motivation, broadens their insights, and offers enjoyable learning circumstances. Despite the opportunities, there were also some drawbacks concerning the lack of intelligibility which generates learning anxiety and technical issues concerning signal stability.
\end{abstract}

Kata kunci:

Pembelajaran daring

Webinar

Skype

ELT

$E L L$

\begin{abstract}
Abstrak
Studi ini melaporkan pengalaman belajar pertama 30 siswa saat menggunakan Skype dalam seri webinar pengajaran Bahasa Inggris (ELT). Seiring jumlah webinar dalam bidang ELT yang berkembang pesat sepanjang situasi pandemi korona pada tahun 2020, penggunaan berbagai platform daring untuk memfasilitasi acara tersebut pun turut merebak. Skype, sebuah aplikasi daring yang dirilis pada tahun 2003, tidak banyak digunakan oleh para peserta dalam penelitian ini sebagai platform sinkron virtual pembelajaran Bahasa Inggris (ELL). Alhasil, banyak dari mereka yang tidak mengenal aplikasi ini. Mendasari kerangka reflektif Gibbs, pencarian kualitatif ini mendokumentasikan kekurangan dan kelebihan yang dihadapi oleh partisipan dalam penelitian ini melalui jurnal refleksi yang mereka tulis. Temuan penelitian ini menunjukkan bahwa webinar berbasis Skype menstimulasi motivasi belajar siswa, memperluas wawasan mereka, dan menawarkan suasana belajar yang menyenangkan. Terlepas dari manfaat-manfaat yang ditawarkan, ada juga beberapa kelemahan yang terkait dengan kurangnya pemahaman terhadap materi yang menimbulkan kecemasan belajar dan masalah teknis dalam kaitannya dengan stabilitas sinyal.
\end{abstract}

${ }^{1}$ Universitas Siliwangi, Tasikmalaya, Indonesia

Email: arininurul@unsil.ac.id

${ }^{2}$ Universitas Islam Syekh Yusuf, Tangerang, Indonesia

Email: tramalia@unis.ac.id

3 Universitas Siliwangi, Tasikmalaya, Indonesia

Email: fuad.abdullah182@gmail.com

Received: February 27, 2021; Received in revised form: March 10 2021; Accepted: March 11, 2021; Available online: March 30, 2021

This is an open access article under a Creative Commons Attribution-NonCommercial-ShareAlike 4.0 International License 


\section{INTRODUCTION}

The worldwide corona pandemic has constructed a different learning circumstance, shifting formal face-to-face meetings into online learning. This condition has opened a vast opportunity for a webinar to spread around the educational environment. Webinar as a combination of web and seminar, which means a seminar over the internet has gained more popularity recently, even though "it [still] needs to develop its potential as an interactive forum and cost-effectiveness" (Verma and Singh, 2010, p.135). Research on utilizing webinars has also been growing alongside its massive usage in the teaching and learning milieu. Topor and Budson (2020) contribute their notion about how to present a practical webinar.

Moreover, Alshahrani (2019) discussed the faculty and students' experience conducting online teaching through the webinar. Before this, Eaton (2010) and Stein, Shibata, Bautista, and Tokuda (2010) researched the webinar's initial experience using Skype. Some other research also focused on utilizing Skype as an online learning platform (see Dharma, Asmarani, and Dewi, 2017; Yen, Hou, and Chang, 2015; Mullen, Appel, Shanklin, 2009). While previous studies concerned using webinar and Skype in separated topics, this present study sheds light on the use of Skype as an online webinar platform explicitly utilized to learn the English language.

Skype is a free communication tool that allows users to make audio and video calls over the internet, primarily used in 2003 (Bonfiglio, Mellia, Meo, Ritacca, and Rossi, 2008). It provides a computer-to-land-line service that can be utilized both for local and international calls, a fee-based service (Eaton, 2010). This application has been widely used to teach foreign languages. Arani (2018) investigates the use of blended-mobile learning using Skype in advancing students' academic writing. Ashrapova, Svirina, and Litvinenko (2020) even compared the use of Skype vs Brick-and-Mortar Learning in teaching a foreign language to gifted children. Yen, Hou, and Chang (2015) applied role-playing Skype-based activities in English language learning and reported a gradual decrease in the students' speaking errors and continuous improvement of their speaking skills. In short, Skype has been positively contributing to the students' language learning development. Due to its effectiveness and utility, Skype was used by a university in Indonesia to facilitate an English Language Teaching (ELT) webinar series, which involved 269 participants from across Indonesia and beyond.

In adapting to any technological learning platform, both teachers and students frequently encounter some challenges. Concerning those challenges, Gillet-Swan (2017) mentions that some academic staff found it challenging to adapt to the online environment since it requires higher technological competency levels. Song, Singleton, Hill, and Koh (2004) contend some challenges encountered by the students in joining the online learning concerning technical problems, a perceived lack of sense of community, time constraints, and the difficulty in understanding the online objectives courses. Nevertheless, benefits are also obtained from utilizing these learning modes, such as accessibility, flexibility, interactivity, and collaboration (Liang and Chen, 2012). Underpinning the notions of existing potential benefits and challenges in online learning, this present study investigates the use of Skype in the ELT webinar series as the students' learning platform. Moreover, to delve deeper into the participant's experience, the investigation was guided by the framework of reflection (Gibbs, 1988).

It is believed that reflection enables students to evaluate their learning activity to reflect on the previous activities and think consciously of what needs to be improved in the future. In line with this, Gibbs (1988) suggests that to give structure to learning from experiences. It would be helpful to follow a framework for examining experiences, and given its cyclic nature lends itself particularly well to repeated experiences, allowing you to learn and plan from things that either went well or did not go well. This framework consists of six stages covering description, feelings, evaluation, analysis, conclusion, and action plan. In the description stage, participants explain the background information of the event, including 'what, when, where, who, why, and how. Then, 
they reveal their feelings and thoughts before, during, and after the situation takes place in the Feeling stage. In the evaluation stage, participants have a chance to evaluate the situation as objectively and as honest as possible.

\section{METHODS}

Based on a descriptive case study as the research design, this study attempts to describe an intervention or phenomenon and the real-life context in which it occurred (Yin, 2003). The investigation mainly focused on the students' experience in joining a webinar series held by a university in West Java, Indonesia, using Skype. Yin (1984) mentions that a case study is a unique way of observing any natural phenomena in a data set. Therefore, to explore the participants' experiences when taking part in the webinar, this study is conducted.

This study's participants were 30 undergraduate students who took part in the webinar series from one university in Tangerang, Banten, consisting of 26 females and four males. They also have various ages and GPA, as shown in the following tables.

Table 1. Ages of the Participants

\begin{tabular}{|c|c|c|c|c|c|}
\hline Ages & 17 & 18 & 19 & 20 & 21 \\
\hline Number of Participants & 1 & 4 & 12 & 10 & 3 \\
\hline
\end{tabular}

Table 2. Range of GPA of the Participants

\begin{tabular}{|l|c|c|c|}
\hline Range of GPA & $3.20-3.50$ & $3.51-3.70$ & $3.71-3.90$ \\
\hline Number of Participants & 3 & 6 & 11 \\
\hline
\end{tabular}

There were twelve sessions provided in the webinar series covering diverse issues: tips for public speaking, a good listener starts from a good speaker, translation method, maintaining identity, teaching grammar and structure and learning English pronunciation. Each participant was given the freedom to register for any of the sessions, depending on their topic interests. The duration of the webinar was around one hour. The participants attended the presentation session and were allowed to pose questions after all, and conducted a discussion.

\section{Data collection procedures}

In answering the research question, the data was collected through the documentation technique. The participants of this study were encouraged to share their experiences in a reflective journal written in English following the stages in Gibb's (1988) reflective framework to review their feelings and thoughts throughout the activities they had attended in the webinar series. Before the reflection, the participants were given an understanding of the stages. It was given in the framework and provided examples on how to make the reflection. From 30 participants, there were 155 pages of reflective journals gathered. Initially, the participants were asked about their readiness as volunteers to contribute to this research project.

\section{Data analysis technique}

After the data was collected, Braun and Clarke's (2006) thematic analysis was employed to organize the data. It was also conducted to identify, analyze, and report patterns within the data. They maintain, "it minimally organizes and describes the data set in rich detail" (Braun and 
Clarke, 2006, p. 6). There are six phases in thematic analysis, namely: "familiarizing [ourself] with [the] data, generating initial codes, searching for themes, reviewing themes, defining and naming themes, and producing the report" (pp. 16-23). Drawing on the opportunities and challenges discovered from the students' reflective journal based on Gibbs' (1988) reflective framework, there were three significant themes concerning opportunities, including stimulating learners' motivation, broadening insights into English language teaching and providing joy when learning. There were two emergent themes on the part of challenges: coping with the technical issues, lack of intelligibility which generates learning anxiety.

\section{FINDINGS AND DISCUSSION}

\section{Opportunities Gained throughout the Webinar and Beyond}

Stimulating learners' motivation

As scientific dissemination forums, ELT conferences and seminars promote the development of more knowledgeable, confident, and motivated ELT professionals committed to their professional development, who see themselves as part of a global ELT community (Borg, 2015). Although his research focused on the ELT offline conference, the students attending the virtual seminar also maintained similar experiences.

P1 I kind of feel envious of the moderator and the presenters because they can talk fluently and confidently in full English. It is still hard for me to do it, so it will motivate me to practice more.

P6 After I followed and listened to some of the presenter talking during the webinar event, I plan to get used to reading books more actively and often practice speed reading, especially when things are urgent or in a hurry.

P23 This seminar became a motivator for other participants and me. I could also be more courageous to try to talk. After I attended the seminar, I felt lucky, happy and excited to continue learning and improving my speaking skill. I'm amazed by all the presenters. They are still students but have good speaking abilities. This seminar was one of my valuable experiences.

P3o This free webinar can be a motivation for students to be more active even with a limited duration. I can also see new people and learn from their pronunciation, which is very good compared to mine and that can make men motivated and a reference so I can study harder.

These original excerpts were taken from the students' reflective journals in July 2020.

After conducting the Skype exchange activities through the webinar series, it is reported that there was increased motivation as a result of the participants' engagement. "Possible reasons include the result of exposure to stimulating and authentic learning contexts, and of collaborative work in a less-threatening environment" (Freiermuth and Jarrell in Ockert 2017, p. 12). As the inherent belief to guide individual learning goal, induce learning behaviors to make continuous efforts, reinforce cognition history, and strengthen and improve the learning outcome (Salleh, Hussein, Mohamed, Karim, Ahlan, and Aditiawarman, 2012), motivation could trigger the students to "make decisions, and acquired fun and sense of achievement in the process" (Lin, Chen, and Liu, 2017, p. 3356). Skype as a digital learning platform is believed to enhance learning interests to make learning more efficient and promote learners' learning persistence (Kaklamanou, Pearce, and Nelson, 2012). In other words, the use of Skype as the virtual synchronous platform in the webinar series boosted the participants' learning 
motivation. It definitely would impact the participants' learning outcomes since Sabhasz (2012) argues that learners with higher learning motivation would present higher learning outcomes since there is a positive correlation between learning motivation and learning outcomes.

\section{Broadening insights in the area of English language teaching and learning}

As an online learning platform, webinar helps students overcome the digital divide and offer a great platform across the globe to share knowledge with [anyone] of various institutes scattered over vast geographical boundaries (Verma and Singh, 2009). Since the webinar participants were students in teachers' training faculty, this webinar also contributes to the development of their pedagogical knowledge as prospective teachers. Rao (2019) claims that "webinars on ELT provide the latest information to the English teachers to update their knowledge and teaching skills, they are more useful in modern classrooms. There are tremendous changes in ELT, and there have been discovered the latest methods, approaches, and modern techniques. It is [not] impossible for all the teachers of English to have the knowledge of these latest issues [by contributing to an online seminar] (p.376)." Additionally, Emre (2019) also implies that webinars would have given the teachers many inputs and experience to boost their professional development. The following statements support the notions,

P12 Before I joined this event, not much I knew about reading extensively. After joining, I was able to gain new knowledge about extensive reading and the strategies to read extensively.

P15 After participating in the webinar "encouraging university students to read extensively", I can read English book well since Ifollow the tips and tricks that they provided during the webinar, and even I can transfer this knowledge to the school children around my house so that they could have an understanding on how to read English book better.

P 21 This led to a positive direction because it shares valuable knowledge so that anyone could take advantages of the content, such as being able to learn about grammar and written structures.

P 26 In this seminar, I can understand that listening teaches me to speak. After listening, I can find new vocabulary and learn good pronunciation by watching the speaker's lips movements. Learning to speak in English is quite tricky so we have to try a lot, repeat and practice.

These original excerpts were taken from the students' reflective journals in July 2020.

From the excerpts, it is understood that the participants have obtained a lot of inputs in various areas in English language teaching and learning, such as extensive reading, grammar and structure, pronunciation, listening, and speaking skills. In this respect, Başaran (2014) mentions that webinars can be practical tools for teaching and learning English, especially for developing the students' listening and speaking skills. It is in line with Rao's (2018) statement claiming that 'as the free webinar is organized, there are plenty of opportunities for the English teachers and learners to update their English language teaching and learning skill' (p. 54). He continues that even though webinars provide some drawbacks, especially concerning the short period, they offer more detailed knowledge about the presented subject. Given this fact, the participants would obtain invaluable information 
about the up-to-date strategies, techniques, methods, and English language teaching approaches and learn from those webinars. Thus, the English learners must engage actively in the ELT webinars to upgrade their knowledge in the English teaching arena and develop their language skills. To support, Budiana and Yutanto (2020) strengthen this notion by researching the advantages of attending ELT webinars towards the students' speaking skills. From the finding, it is concluded that the webinar has contributed positively to the enhancement of non-native English-speaking students.

\section{Providing joy when learning}

Creating an enjoyable atmosphere in the ELT learning circumstances is amongst the strategies to present the students' positive emotions, moreover in an online learning environment. Zembylas (2008) claims that some possible positive emotional presence in online learning included joy, enthusiasm, and excitement for online learning flexibility. The intensity will be more intensive and frequent in earlier periods of online learning. Clay (2012) implies in his book that tremendous and effective webinars enable the participants to experience captivating, informative, and fun learning circumstances through their extensive modes of learning. Similarly, the students attending the ELT webinar series reveal their positive feelings throughout the webinars in the following excerpt,

P $5 \quad$ I also feel happy to be able to attend the webinar and add insight. Besides, I also got new friends from various universities in Indonesia and even universities from abroad. I also feel happy to get to know the students who held this seminar because they are very friendly, good at talking to many people.

P $6 \quad$ I felt happy for so many reasons. First, I could have new online friends, and I reunify with my high school seniors. Secondly, this webinar is exciting, engaging, and full of admiration.

P $8 \quad$ I began to subside because it turned out that it was fun to get new knowledge this way.

P $16 \quad$ During this webinar, I enjoyed listening carefully to what the presenters said. Ifelt so excited because this is my very first time joining a webinar via Skype.

These original excerpts were taken from the students' reflective journals in July 2020.

The students' learning convenience should be the first consideration when teachers expect the students' learning engagement. Providing webinars as the learning platform would help them accommodate enjoyable learning situations. Pardede (2012) maintains that webinar enables teachers and students to conduct virtual classrooms where they have classes without being physically present in the classroom. Moreover, various devices, like chat, forum, and Skype, are available to facilitate online communication. He continues that "to a certain extent, such forums provide the students with a less stressful practice environment for the target language so that every student will be engaged in the learning process" (p. 171). In short, the Skype-based webinar series in this context has provided opportunities to experience an enjoyable learning atmosphere for most of the participants in this study.

\section{Unbearable Constraints During Webinar}

Despite the opportunities provided by the Skype-based webinar, drawbacks also appeared as some hindering issues in the learning process. In this respect, the lack of intelligibility generating students' learning anxiety and low signal stability/technical issues emerged as the two central themes. 


\section{Lack of intelligibility generating learning anxiety}

One of the challenges of online ELT forums is the students' lack of intelligibility. Some students revealed their inability to catching some information delivered in the webinar series. They mentioned several reasons contributing to their failure in grasping the messages, as follows.

$P_{3} \quad$ It was difficult for me to understand what was being said because the sound is not very clear. Besides, my listening skill is also not good. However, at least I could catch a few essential points.

They could deliver the material very well, but they spoke too fast. It

P9 made me a little bit difficult to understand.

I began to worry because I did not understand what the speakers

P15 were presenting during the webinar. I only understood some parts of it because the speaker delivered the material fully English. They also spoke without pauses. That was what worries me.

The moderator and the speakers spoke in full English. They already have outstanding English skill, and one of them was very fast in P16 speaking, which caused a little difficult for me to understand the material delivered.

These original excerpts were taken from the students' reflective journals in July 2020.

The students' ability to get English oral texts have influenced their ability to understand the messages (Hidayati, Dewi, Nurhaedin, and Rosmala, 2020). They continue that the 'inadequate listening proficiency' involves 'inability to deal with the rapid speech rate and range of lexical choices' are the contributing factors (p.1). This condition led the students to experience learning anxiety. The following excerpts provide the evidence,

P1 Before the webinar started, I felt so nervous because that was my first time joining a webinar. When the presenters started to present their material, I felt so confused. I thought the others also felt the same.

$\mathrm{P} 4 \quad$ I was very excited and nervous at the same time because it was the first time, and I was afraid of making unintentional mistakes.

$\mathrm{P}_{5} \quad$ Before the event started, I was already nervous and scared because it was the first time I attended a webinar. I felt uncomfortable and confused because of many people that I did not know. I did not know what to respond to and how to attend the activity.

I had prepared myself before joining live on skype. I was so

P9 nervous.

These original excerpts were taken from the students' reflective journals in July 2020.

This issue is relevant to what Zembylas (2008) mentions. There is the possibility of experiencing negative emotions such as fear and anxiety for the unknown mode of online learning and its demands, especially those who are novel to it. Additionally, the Skype-based webinar was a sharing activity involving the presenters and audiences. Hillard, Kear, Donelan, and Heaney (2020) maintain that even previous research has identified that working with other students online can cause anxiety for learners who may affect their 'participation and performance' (p. 3). Saadé, Kira, Mak, and Nebebe (2017) also reveal their research findings that ' $30 \%$ of students seem to experience anxiety with online courses. Female students are 
more anxious about taking online courses than male (p.1). It is now evident that to obtain sufficient inputs. The students need to be more prepared and selective when attending a particular webinar considering their capability.

\section{Technical Issue/Insufficient Signal Stability}

Even though online learning provides many opportunities, technical difficulties somehow become one drawback to increasing this medium (Sitzmann, Elly, Bell, Bauer, 2013). This issue has appeared as another challenge in conducting the webinar series. Below are the students' responses related to the issue of signal and technical aspect during the webinar.

P1 The webinar did not go so well. Bad connection affects the way the presenters' talk has become an issue for me. We tried to tell the moderator (about the condition), and she said sorry for the troubles.

P4 In the middle of the presentation, suddenly, there was a technical error. The presenter's microphone was off so that participants could not hear the presentation.

P7 All the material delivered by the presenters is quite excellent and straightforward, but there are a few obstacles to network connection from some presenters. Fortunately, this can be

P12 overcome immediately.

There is one of the presenters who got trouble with signal stability during the presentation. It took a few minutes to replace with a

P18 better signal, and I think it is a bit of a waste of time.

A presenter delivered the material, but he forgot to activate the audio so that no one could hear the presenter's voice.

These original excerpts were taken from the students' reflective journals in July 2020.

Online learning is a new deal in Indonesia. Since the beginning of the Covid-19 outbreak, the learners are ubiquitously required to adapt to new learning habits. It is not easy since they need to deal with a novel circumstance. Considering Indonesia's geographical situation consisting of mountains and low areas, it certainly affects the signal stability, especially for students who live in suburban areas, who hardly get a stable signal. Weather problems can also affect stability.

Meanwhile, the limited or restrictive internet capacity would impact the students' learning engagement in online learning (Anthony and Keating, 2013). Unfortunately, the webinar series did not offer a complete learning engagement to some students having poor connections since they do not fulfil the criteria to be ready for access to ICT. It is in line with Rooksby, Weckert and Lucas's (2002) notions mentioning that access, ability, and affordability are three pivotal components to technology readiness. Access is a coin that is defined as someone being able to access the internet from their home, community, or a public place. Also, it includes the physical elements of access to ICT such as 'basic computer facilities, word processing, data storage and printing, web browsing, searching and discussion mediums' (Black and Atkinson, 2007, p. 4).

Meanwhile, Rooksby, et al. (2002) explains that ability is the training and support needed to utilize ICT, and affordability is the material cost of ICT access. The cost factor is always an issue for most Indonesian learners, so access becomes a barrier to computer technology. Moreover, Roberts and McInnerney (2007) elucidate that some of the fundamental problems related to the digital divide, or barriers to technological access, involve 
'access to knowledge, access to technology, access to communications, access to control, access to goods and commodities and access to participation (p. 257).

Technical issues could happen for many reasons. For example, it could happen because they are less provided by technological knowledge or less prepared. Gelatt (1995) mentions that [the learners] must be ready for changes since the changes are so rapid, turbulent, and unpredictable. It is true that we now live in a time of technology. Therefore, the students must be provided with adequate skills and knowledge on technology to ease them adapt to the times. In this respect, the providers are also expected to increase their quality in signal services and lower prices to facilitate their needs.

\section{CONCLUSION}

In a technological-based teaching milieu today, teachers need to consider the appropriate learning platforms that can access most of the students' learning territory. As the recent learning trends, Webinars could be utilized as an alternative solution to answer the 21stcentury teaching challenge. A skype-based webinar is applicable in online learning circumstances, more specifically in English language teaching. Students will not only improve their language skills but also their pedagogical competence as prospective teachers. Although some drawbacks might also be present, the potentials to learn from webinars is widely open in this current condition. This research has some weaknesses, especially regarding data collection techniques. The further researcher could elaborate on more techniques to obtain more saturated data and comparable findings. Additionally, further research could also expand on webinars' possibilities to conduct across the diverse level of age and education; primary, secondary or high schools. Furthermore, gender differences in utilizing technology, especially webinars, might also be an exciting area to elaborate.

\section{REFERENCES}

Alshahrani, I. (2019). Orienting Faculty and Students with Online Teaching Webinar Experiences in Saudi Arabia. Annals of Medical and Health Sciences Research 9 (1).

Anthony, S. G., \& Keating, M. S. (2013). The difficulties of online learning for Indigenous Australian students living in remote communities-it's an issue of access. Online Journal of Distance Learning Administration, 16 (2).

Arani, J. A. (2018). Advancing academic writing in a mobile Skype-based blended model. International Journal of Interactive Mobile Technologies, 12(3), 86-103.

Ashrapova, A. K., Svirina, L. O., \& Litvinenko, E. V. (2020, May). On Learning via Skype vs Brick-and-Mortar Learning: The Experience of Teaching a Foreign Language to Gifted Children. International Scientific Conference "Digitalization of Education: History, Trends and Prospects." (DETP 2020) (pp. 570-573). Atlantis Press.

Baez, J. C., \& Marquart, M. S. (2020). Webinar\# 2: Trauma-informed teaching \& learning (TITL) online (Zoom version).

Başaran, B. Ç. (2014). Webinars as instructional tools in english language teaching context (Master's thesis).

Black, R., \& Atkinson, J. (2007). Addressing the Digital Divide in Rural Australia. Sic erat in fatis (so it was fated). 45-62.

Bonfiglio, D., Mellia, M., Meo, M., Ritacca, N., \& Rossi, D. (2008). Tracking down skype traffic. In IEEE INFOCOM 2008-The 27th Conference on Computer Communications (pp. 261265). IEEE.

Borg, S. (2015). The benefits of attending ELT conferences. ELT journal, 69(1), 35-46. DOI: 10.1093/elt/ccuo45 
Braun, V., \& Clarke, V. (2006). Using thematic analysis in psychology. Qualitative research in psychology, 3(2), 77-101.DOI: 10.1191/1478088706qpo630a

Budiana, K. M., \& Yutanto, H. (2020). Webinar: A Strategy to Enhance Speaking Skill of Nonnative English Speakers. Journal of English Educators, 5(1), 3137.DOI: https://doi.org/10.21070/jees.v5i1.354

Clay, C. (2012). Great webinars: create interactive learning that is captivating, informative, and fun. John Wiley \& Sons.

Dharma, H. R. C., Asmarani, D., \& Dewi, U. P. (2017). Basic Japanese grammar and conversation e-learning through Skype and Zoom online application. Procedia computer science, 116, 267-273.DOI:10.1016/J.PROCS.2017.10.055

Eaton, S. E. (2010). How to use Skype in the ESL/EFL classroom. The Internet TESL Journal, 16(11), 1-14.

Emre, S. (2019). Webinars for teaching English as a foreign language and for professional development: teacher perceptions (Doctoral dissertation, Bilkent University).

Freiermuth, M., \& Jarrell, D. (2006). Willingness to communicate: Can online chat help? International Journal of Applied Linguistics, 16(2), 189-212. https://doi.org/10.1111/j.1473-4192.2006.00113.x

Gelatt, H. B. (1995). Future sense: Creating the future. The Futurist, 3 (2), 35-43.

Gibbs, G. (1988). Learning by doing: A guide to teaching and learning methods. Oxford: Further Education Unit.

Gillett-Swan, J. (2017). The challenges of online learning: Supporting and engaging the isolated learner. Journal of Learning Design, 10(1), 20-30. DOI: 10.5204/jld.v9i3.293

Hidayati, A. N., Dewi, N. S. N., Nurhaedin, E., \& Rosmala, D. (2020). Foreign Language Listening Anxiety in an Academic Listening Class. J-SHMIC: Journal of English for Academic, 7(2), 1-9. DOI: https://doi.org/10.25299/jshmic.2020.vol7(2).5241

Hilliard, J., Kear, K., Donelan, H., \& Heaney, C. (2020). Students' experiences of anxiety in an assessed, online, collaborative project. Computers \& Education, 143, 103675. DOI: https://doi.org/10.1016/j.compedu.2019.103675

Kaklamanou, D., Pearce, J., \& Nelson, M. (2012). Food and Academies: A Qualitative Study. Department for Education, 1-23.

Liang, R., \& Chen, D. -T. V. (2012). Online learning: Trends, potential and challenges. Creative Education, 3(8), 1332-1335. http://dx.doi.org/10.4236/ce.2012.38195

Lin, M. H., \& Chen, H. G. (2017). A study of the effects of digital learning on learning motivation and learning outcome. Eurasia Journal of Mathematics, Science and Technology Education, 13(7), 3553-3564. https://doi.org/10.12973/eurasia.2017.00744a

Marquart, M. S., \& Counselman Carpenter, E. A. (2020). Webinar\# 3: Inclusive online teaching and teachable moments in online classrooms (Zoom version). https://doi.org/10.7916/d8-q1zt-av34

Marquart, M. S., \& Garay, K. (2020). Webinar\# 1: The basics of online student engagement and online instructor presence (Zoom version). https://doi.org/10.7916/d8-2wvg-3s49

Mullen, T., Appel, C., \& Shanklin, T. (2009). Skype-based tandem language learning and web 2.0. In Handbook of research on Web 2.0 and second language learning (pp. 101-118). Igi Global. DOI:10.4018/978-1-60566-190-2.CHoo6

Ockert, D. (2017). The positive influence of Skype exchanges on Japanese elementary students' affect. Accents Asia, 9(2), 11-15.

Pardede, P. (2012). Blended Learning for ELT. Online Submission, 2(3), 165-178.

Rao, P. S. (2018). Webinars as Instructional Tools in English Language Context. Literary Endeavour, 9, 152-162. 
Rao, P. S. (2019). The Use of Mobile Assisted Language Learning (MALL) Technology in Teaching and Learning in English Classrooms. Research Journal Of English (RJOE), 4(2), 225-238.

Roberts, T. S., \& McInnerney, J. M. (2007). Seven problems of online group learning (and their solutions). Journal of Educational Technology \& Society, 1O(4), 257-268.

Rooksby, E., Weckert, J., \& Lucas, R. (2002). The rural digital divide: the ruralsociety. Rural Society, 12(3), 197-210. DOI: 10.5172/rsj.12.3.197

Saadé, R. G., Kira, D., Mak, T., \& Nebebe, F. (2017, June). Anxiety \& Performance in Online Learning. In I n SITE 2017: Informing Science \& IT Education Conferences: Vietnam (pp. 147-157). DOI: $\underline{10.28945 / 3736}$

Salbego, N. N., \& Tumolo, C. H. S. (2015). Skype Classes: Teachers and students' perceptions on synchronous online classes in relation to face-to-face teaching and learning. International Journal of Language and Applied Linguistics, 1(3), 36-45.

Şahbaz, N. K. (2012). Evaluation of reading attitudes of 8th grade students in primary education according to various variables. Educational Research and Reviews, 7(26), 571-576.

Salleh, N., Hussein, R., Mohamed, N., Karim, N. S. A., Ahlan, A. R., \& Aditiawarman, U. (2012). Examining information disclosure behavior on social network sites using protection motivation theory, trust and risk. Journal of Internet Social Networking \& Virtual Communities, 2012, 1. DOI: 10.5171/2012.281869

Sitzmann, T., Ely, K., Bell, B. S., \& Bauer, K. N. (2010). The effects of technical difficulties on learning and attrition during online training. Journal of Experimental Psychology: Applied, 16(3), 281. https://doi.org/10.1037/a0019968

Song, L., Singleton, E. S., Hill, J. R., \& Koh, M. H. (2004). Improving online learning: Student perceptions of useful and challenging characteristics. The internet and higher education, 7(1), 59-70. http://dx.doi.org/10.1016/j.iheduc.2003.11.003

Stein, Gerald H., Ayako Shibata, Miho Kojima Bautista, and Yasuharu Tokuda. "Webinar: An initial experience with web-based real time interactive clinical seminars for Japanese medical students." General Medicine 11, no. 2 (2010): 87-90.

https://doi.org/10.14442/general.11.87

Topor, D. R., \& Budson, A. E. (2020). Twelve tips to present an effective webinar. Medical teacher, 42(11), 1216-1220. https://doi.org/10.1080/0142159X.2020.1775185

Verma, A., \& Singh, A. (2009, August). Leveraging webinars for student learning. In 2009 International Workshop on Technology for Education (pp. 86-90). IEEE. DOI: $10.1109 /$ T4E.2009.5314105

Verma, A., \& Singh, A. (2010). Webinar-Education through digital collaboration. Journal of Emerging Technologies in Web Intelligence, 2(2), 131-136. doi:10.4304/jetwi.2.2.131-136

Yen, Y. C., Hou, H. T., \& Chang, K. E. (2015). Applying role-playing strategy to enhance learners' writing and speaking skills in EFL courses using Facebook and Skype as learning tools: A case study in Taiwan. Computer Assisted Language Learning, 28(5), 383-406. https://doi.org/10.1080/09588221.2013.839568

Yin, R.K., (1984). Case Study Research: Design and Methods. Beverly Hills, Calif: Sage Publications.

Yin, R. K. (2003). Designing case studies. Qualitative Research Methods, 359-386.

Zembylas, M. (2008). Adult learners' emotions in online learning. Distance Education, 29(1), 71-87. DOI: $\underline{10.1080 / 01587910802004852}$ 